\title{
NON-VIOLENCE PRINCIPLES IN KING'S SPEECHES AND ITS IMPACTS TO AFRICAN AMERICAN SOCIETY
}

\author{
Eryn Gemala Putri \\ gemala.p@gmail.com
}

\begin{abstract}
This paper is aimed to analyze the non-violence principles in Martin Luther King's speeches and the impacts to African American society and reveal the consistency of King in practicing non-violence principles. This study is a qualitative research, which is conducted under a library research. To describe and analyze non-violence principles in King's speeches, the writer applied American Studies perspective of interdisciplinary approach. Therefore, it applies a number of related approaches in an integrated way: literature, social, and culture. The result of this research reveals that Martin Luther King is consistent in applying non-violence principles. Applying non-violence principles gives impacts to African American society. Desegregation in public facility and the legalization of voting right for African American society are the impacts of non-violence principles that initiated by King.
\end{abstract}

Keyword: non-violence principles, impacts of non-violence principles, public desegregation, speech.

\section{Introduction}

Speech is one of the media that people can use to convey their ideas toward certain important occasion. Many influential people in the world such as: Martin Luther King Jr, Mahatma Gandhi, and Ir. Soekarno use speech as the media to lead movement. Martin Luther King is one of the prominent figures in African American history. King actively participated in civil right movement by giving speeches and leading several demonstrations and marches as his effort to eliminate segregation that occurred (Puckrein, p. 5). His contribution and his concept in gaining racial equality for African Americans make him a distinctive figure.

Besides King's speeches give inspiration and enlightment to his readers, his speeches also reflected the social condition of African Americans who struggled hard to face racial segregation in United States around 1960's. At that time, African Americans were not treated equally by the Whites. They had their own public facility and it was forbidden to them to use public facility that owned by the Whites (Johnson 1999: 891). Several ways are applied by the African Americans to fight against racial segregation. Leading a movement is one of the ways that African Americans use in fighting against racial segregation. Besides leading movement, African Americans also held a demonstration or march as their way to fight against racial segregation.

Martin Luther King was born on January 15th 1929. King attended segregated public schools in Georgia and graduated from high school at the age of fifteen. He received the B.A. degree in 1948 from Morehouse College; a distinguished Negro institution of Atlanta from which both his father and grandfather graduated. 
In 1954, Martin Luther King became pastor of the Dexter Avenue Baptist Church in Montgomery, Alabama. He was a strong worker for civil right movement. Because of his hard work, he accepted the leadership of the first great Negro leader demonstration of contemporary times in the United States. In 1957, he was elected president of the Southern Christian Leadership Conference, an organization formed to provide new leadership for the new burgeoning civil right movement. Between 1957-1968, King traveled over six million miles and spoke over twenty-five hundred times, appeared wherever there was injustice, protest, and action. In these years, he led a massive protest in Birmingham, Alabama, that caught the attention of the entire world (Bruns: 11-14).

In King's speeches, the struggle of African Americans in gaining racial equality can be seen. Not only become the reflection of the situation that happened in United States during segregation era, King's speeches also contain the non-violence principles that become the guideline for King and his followers to face the violence, riots, and discrimination that happened in United States. Feeling curiosity with this literature phenomenon, a research is done to analyze this phenomenon. What non-violence principles that King initiated and the impacts of non-violence principles become elements to be investigated in this research. Whether King is consistent in practicing his own non-violence principles is also analyzed here.

Five speeches from Martin Luther King are used as the data because they represent the struggling that African Americans face at that time. The way of King in delivering and persuading his audience is one of the reasons this research is done. Hopefully this research gives new information about non-violence principles that were practiced by African Americans during the segregation era.

This paper, thus, is focused on speeches that have similar issue which were delivered by Martin Luther King. There are five speeches from Martin Luther King, which are:

Rediscovering Lost Values, Speech at Green March on Detroit, A Letter from Birmingham Jail, Our God is Marching On, and Loving Your Enemies. From those speeches, the struggle for gaining the equality for African Americans is revealed. Each speech pictures the difficulties that King faced for gaining the equality of his race and shows his way in practicing nonviolence principles. The analysis is limited whether King is consistent in practicing nonviolence principles and the impacts of nonviolence principles for African Americans struggle in gaining racial equality.

\section{Methodology}

This research is qualitative study by using descriptive-explanatory way of discussion. According to Creswell in his book Qualitative Inquiry and Research Design, qualitative research is an inquiry process of understanding based on distinct methodological traditions of inquiry that explore a social or human problem. The main and supporting data are gathered from various journals, books, articles from library and internet that focus on speeches that were delivered by Martin Luther King. This thesis analyzes five speeches that have similar theme which is non-violence. This thesis uses library research, a research that based on any literature on library or internet as well and collect information from textbooks. The focus of this study is to see the consistency of King in applying non-violence principles and to reveal the impacts of non-violence principles in African Americans life. The method of 
collecting data is by downloading all the speech texts through internet. Five speeches are selected based on the similarity of their themes. Five speeches are chosen for they contain the same theme which is non-violence principles that King proposed. The selection of the data was based on criterion sampling based on Patton (1990) stated that:

The logic of criterion sampling is to review and study all cases that meet some predetermined criterion of importance ... to understand cases that are likely to be information-rich because they may reveal major system weaknesses that become targets of opportunity for program or system improvement (176-177).

Because this is an interdisciplinary research, every book and journal that relate with this research also collected through internet and library. These information are used to give a better understanding. After collecting the data, the speeches are analyzed one by one so the consistency of King in applying non-violence principles can be revealed. After the speeches that contain non-violence principles collected, the analysis starts from categorizing the data gathered, choosing the data needed, analyzing the case from data, presenting the result, and drawing the conclusion. Additional information are also added in analyzing speeches to give detail analysis of the non-violence.

\section{Discussion}

\section{A Way of Life for Courageous People}

This principle is one of the non-violence principles proposed by King in his book entitled Strive To Freedom. Martin Luther King states that applying the non-violence principles needs courage. The courage that King means is the bravery and faith in applying the principles. This means that non-violence principles can only be practiced by brave people. The courageous of African Americans can be seen through King's speeches. In his speeches King pictures the bravery of African Americans to practice the non-violence principles.

By not using violence, it does not mean that African Americans are coward. Applying nonviolence principles needs courage and faith. Through speeches that were delivered by Martin Luther King, it can be seen that African Americans take the risks in applying nonviolence principles. At that time, many of them had to be jailed, kidnapped, even killed. The others still stood to fight their rights.

From a speech that was delivered by Martin Luther King entitled A Letter From Birmingham Jail, it can be seen that African Americans are people who have deep faith and courage in reaching their dream, to be equal with Whites. A Letter From Birmingham Jail was written by King when he was jailed in Birmingham for leading a demonstration in Birmingham. After being released from jail, he had a chance to speak what he wrote in jail (Trotter: 125).

In this speech King spoke, "So we had no alternative except that of preparing for direct action, whereby we would present our very bodies as a means of laying our case before the conscience of the local and national community" (Speech 4: 43-45). This quotes show that King is brave enough to have a direct action as his response to Whites. Here he also assures African Americans to present their bodies which means to take risk as a way to do non-violence principles. In applying non-violence, African Americans have sacrificed what they have. It can be seen from many physical and mental abuses that they received along their survival. Here King reminds African Americans not to stop their struggle and still have spirit and courage to have direct actions. 
Another speech that explains about this principal is Our God Is Marching On. This speech was delivered in Alabama on March 25th. King begins the speech by saying:

"A seventy-year-old Negro woman who lived in this community during the bus boycott-and one day, she was asked while walking if she didn't want to ride. And when she answered, No, the person said, Well, aren't you tired? And with her ungrammatical profundity, she said, My feet is tired, but my soul is rested." (Speech 5: 4-7)

It is an illustration that shows the courage that owned by a seventy years old woman who still commits herself in practicing non-violence. The spirit of this old woman is highlighted by King in order to give the real example how nonviolence principle is practiced. This picture also shows to the Whites that African Americans are people with endless spirit. The courage that they have is the weapon for them to attract Whites' sympathy.

King in this speech highlights the courageous that owned by African Americans that King witnesses through along he led demonstrations and marches. They have walked through desolate valleys and across the trying hills. Their effort is clearly seen and they do not easily give up in spite of many obstacles that they have to face in practicing non-violence principles.

By giving the picture of courageous African Americans in Alabama, King tries to do two things. First it will show to the Whites that African Americans will never stop their fight. They are not coward people who easily give up when they are hurt physically and mentally. Second, it will inspire other African Americans in other places to also have bravery and faith in applying non-violence principles.

\section{Winning for Friendship and Understanding}

Winning friendship and understanding with the Whites is one of the principles that have to be created. King tries to persuade African Americans not to take revenge to the Whites who hurt them. Instead of defeating Whites, King urges African Americans to create friendship with the Whites. Winning friendship and understanding will be the beneficial thing for both sides: the Whites and African Americans. It will make the situation between Whites and Blacks better.

In applying this non-violence principle, the understanding between two sides have to be promoted. Though, the oppressed have experienced a lot of pain from the oppressors, still the understanding and friendship have to be pursued. The importance of this principle can be seen from speeches that were delivered by Martin Luther King when he led march, demonstration, and boycott.

The idea of winning friendship and understanding can be seen from King's speech entitled Loving Your Enemies. In this speech King explains the understanding will never be accomplished if there is still hatred and anger in their hearts. King said that, "The person who hates you most has some good in him; even the nation that hates you most has some good in it; even the race that hates you most has some good in it." (Speech 2: 97-98). These lines refer to the Whites who hate African Americans. Though the Whites have so much hatred to them, King said that there is still good in them. It is not easy for African Americans in the beginning to see the good side of the Whites. However, after the civil right movement occur, several Whites begin to consider that actually African Americans are actually same to them and it 
makes African Americans easier to build understanding with Whites.

Another speech that also discusses the importance of winning friendship is A Letter from Birmingham Jail. Besides this speech talks about the injustice that received by King when he was jailed by the Whites, King said that not all Whites treat Blacks bad. King is still thankful that some Whites respect African Americans by joining demonstration, march, boycott that are initiated by Blacks. King in this speech spoke: "I am thankful, however, that some of our white brothers have grasped the meaning of this social revolution and committed themselves to it. They are still all too small in quantity, but they are big in quality. Some, like Ralph McGill, Lillian Smith, Harry Golden, and James Dabbs, have written about our struggle in eloquent, prophetic, and understanding terms. Others have marched with us down nameless streets of the South. They sat in with us at lunch counters and rode in with us on the freedom rides." (Speech 4: 210-214).

What King said is the proof that winning friendship and understanding will earn something positive. When African Americans apply non-violence principles, some Whites turn their attitude and support them to eliminate any forms of segregation and discrimination. They also participate actively in march or demonstrations that held by African Americans.

It is hard for King personally to understand the injustice that have been done by the White religious leaders. The thing that King can not easily accept is the fact that these White religious leaders oppose him. As religious people, they should be wiser in treating Blacks and not to discriminate them. However, deep in his heart King believes and hopes that the understanding will be earned and more Whites will treat African American as their brothers and sisters not as their enemies.

\section{Choosing Love Instead of Hate}

This is another principle that is proposed and expressed by King in his speeches. The love that King defines in this principle is not merely a melancholy thing. Love is seen as a power to forgive and treat the enemies in a good way. Actually, this principle is adapted from one of Christian teachings. Jesus asked his followers to love their enemies and not to defeat them. In Luke 6:27 - But I say unto you which hear, Love your enemies, do good to them which hate you (www.bible gateaway.com/). This teaching is adapted by King in order to make it easier for African Americans in struggling for their equality. By knowing the reasons and the good results projected in applying this principle, African Americans are expected to apply the non-violence principles in their movement. A speech that explains about the importance of loving enemies in order to gain peace is Great March on Detroit. King states that love is not limited with the definition of affectionate feeling. King said, "I'm talking about something much deeper. I'm talking about a sort of understanding, creative, redemptive goodwill for all men." (Speech 3: 119-120). It has been explained previously that love is a redemptive power. King states again in order to explain that love should not only be interpreted as affectionate feeling. It will be difficult for people who have been abused to have affectionate feeling to people who abuse them. However, when people see love as a power that can redeem and transform people into a better person, it will be easier for the oppressed to love their oppressors.

In this speech King also states that loving enemies is one of the commands from Jesus Christ. King spoke, "But Jesus told us this a 
long time ago. And I can still hear that voice crying through the vista of time, saying, "Love your enemies, bless them that curse you, pray for them that despitefully use you." (Speech 3: 124-126). In spite of much pains that experienced by African Americans, King again reminds them through this speech that African Americans should not curse or hurt their enemies. Jesus asks his followers to bless their enemies by forgiving and loving them. Though it is hard command to do especially for African Americans who receive physical and mental abuse from Whites, King still urges them to love their enemies.

\section{Defeating Injustice not the People}

This is the forth principle that King proposes. This principle holds the belief that the thing that must be defeated in the African American Movement is the injustice itself. It refers to any systems that legalize the injustice to happen. It includes the system of segregation that occurred in the United States. King underlines this concept in order to make African Americans not to defeat the Whites as the oppressors but to defeat any systems that legalize the injustice. In Great March on Detroit, King tries to make African Americans aware of the injustice that they have to face. King says that they cannot wait any longer to be treated unequally. They should do a direct action to stop the injustice. However, King reminds them not to defeat the people but it is the system that must be defeated. In this speech King explains that segregation belongs to injustice system that becomes the social problems in United States. King said, "Segregation is wrong because it is a system of adultery perpetuated by an illicit intercourse between injustice and immorality." (Speech 2: 32-34). This sentence underlines the idea why segregation must be eliminated. In King's opinion segregation involves injustice and immorality in it. In this system, colored people are treated unequally. They cannot use the public facility together with the Whites.

In King's speech entitled Our God Is Marching On, he also explains about this principle that non-violence defeats the injustice. King in this speech mainly discusses about the unequal treatment that African Americans receive in segregation. However King again reminds his audience to never defeat Whites. He said, "And so I plead with you this afternoon as we go ahead: remain committed to non-violence. Our aim must is never to defeat or humiliate the white man". (Speech 5: 214-215). King never hesitates to repeat the principle for not defeating oppressors in applying non-violence. It is very important command for it can change Whites' perception toward Blacks who are regarded as uncivilized people.

\section{Suffering Can Educate and Transform People}

This principle urges African Americans to see the positive side of the suffering. The suffering phase in people's life can transform and educate them. Along with the suffering, people gain power and strength that can transform them into courageous people. The power that they gain along the civil right movement functions as a defensive mechanism to make them survive in the movement. It has been explained, in civil right movement African Americans suffer from physical and mental abuse. To defense and survive, the suffering that they receive creates power as their weapon to fight against racism. Applying non-violence principle means that people must be ready for any consequences. One of the consequences that is possible to happen is being suffered.

In Our God Is Marching On, King portrays how the suffering that African Americans face 
becomes the power for them to fight against the racial injustice that occurred in United States. King spoke, "The confrontation of good and evil compressed in the tiny community of Selma generated the massive power to turn the whole nation to a new course." (Speech 5: 44-46). King explains to his audience that the suffering that African Americans face in Selma somehow gives a positive energy to their struggle. The physical and mental abuse that Blacks receive in Selma turns into power to change the situation in Selma better. A new course that King mentions in this discussed speech refers to the new way of thinking toward the racial injustice issue. The suffering that happens in Selma moves the African Americans to change the perception of the Whites who consider segregation as a legal system.

From what King said in his speech, it can be seen how African Americans have to face the hard time during the segregation era. At that time, Blacks had to see directly when they saw their family members killed. They also received physical abuse even when they were considered as innocent. Because of all injustice that occur to them, King says that the time for fighting against segregation has come. King urges Blacks to use their strength to not be plunged in this injustice system.

\section{Universe is on Side of Justice}

This is the last principle that King proposed. This principal holds the belief that actually the universe is on the side of justice. It means that justice will eventually win. In spite of many injustice cases happened in the universe, at the end justice will win over the injustice. This principal is important for giving a better understanding for African Americans in understanding that justice is important thing. They face injustice treatments and it makes them believe that injustice can not be changed.
However, King through this principal tries to change the perception. King makes them realize that justice will eventually win over the injustice.

King delivers this principle through direct action and speeches. The speech that discusses about this principle is The Great March On Detroit. King portrays the ideal situation that should exist in the United States through his speech. King said, "Yes, I have a dream this afternoon that one day in this land the words of Amos will become real and justice will roll down like waters, and righteousness like a mighty stream." (Speech 3: 203-204). King delivers his dream so that African Americans would realize that justice is not an impossible thing. Justice will happen if they strive to make it exists. The word 'amos' refers to love and King hopes between the Whites and Blacks can love each other. There will not be any injustice cases and justice will exist in every place in the United States. By saying these sentences, King expects that the Whites begin to realize that injustice is totally wrong and it must be stopped.

The Impacts of Non-Violence Movement for African Americans in Gaining Racial Equality Applying non-violence principles gives a new hope for African Americans in gaining racial equality. Before civil right movement, they did not use certain concept or method in fighting against racial injustice. They only used physical strength and violence to respond Whites injustice attitude. Martin Luther King is one of the Black leaders who gives contribution for African American society in gaining racial equality. He initiates a new way in dealing with racial injustice that does not involve violence. Desegregation in public places is one of the positive impacts that was successfully reached by Blacks in civil right movement. African Americans in segregation era received injustice 
treatment from Whites since they were segregated almost in all aspects of life. They could not get proper job, attend the public facility, and also they had to send their children to school that is separated from Whites school (Ladenburg: 16-18). In responding to this, Martin Luther King initiates a new tactic to end the racial injustice that occurred in United States. The principles are seen as the effective weapon to fight against racism. Demonstration, march, sit in, and also boycott were ways that they apply to protest Whites injustice treatment. In spite of obstacles that Blacks face, they persevere to apply non-violence principles in responding Whites injustice treatment.

Several demonstrations were held in the United States during the civil right movement. One of the successful demonstrations that was initiated by King is Memphis Sanitation Worker Strike. This demonstration happened in 1968 as Black workers respond for injustice that they received in their job. 1,300 Black sanitation workers in Memphis protested their terrible working conditions, discrimination, and low pay (Honey: 1-4). This movement can be seen as Black's temptation to gain equality in all aspects. Eventhough Blacks have worked hard still their wage is under the standard. King supports the workers in Memphis to fight against the segregation that occurred to them.

The sit in is another form that African Americans used in gaining equality in public places. The instruction that Blacks do in sit in is only sitting quietly and waiting to be served. Though it seems simple instruction, it is not easy to do since Blacks often received physical abuse during sit in (Friedman: 38). Blacks persevere in applying non-violence through sit in. They do not fight back to Whites who threaten them to stop their struggle. They prove that Blacks stereotype that is created by Whites toward Blacks is totally wrong. They are civilized people with endless courage who never give up in realizing their dream; to be equal with Whites. Sit in finally resulted a remarkable policy that legalizes desegregation in public places.

\section{Conclusion}

From the analysis of speeches that were delivered by Martin Luther King, it can be concluded that Martin Luther King is a consistent leader. King does not only formulate the principles of non-violence but he is persistent in practicing those principles. King actively participates in direct actions that aim to eliminate discrimination and segregation that occurred in United States of America. Being a consistent leader is not an easy job to do. King must face several incidents that endanger him. However, King keeps in faith that practicing non-violence principles would change the life of African Americans so they can be treated equally by Whites.

Martin Luther King initiates his own nonviolence principles that make him different with other leaders. King gives a real example through demonstrations, marches, and boycott that he led. He does not give up though he was jailed in Birmingham. He applies his principles by not taking revenge to Whites who jailed him. Instead of using violence, King prefers to compose and deliver speech as his reaction to Whites. It can be concluded that actually his action is the reflection of the principles that he initiates.

The impacts of non-violence principles that are initiated by King give significant change in African American life. Though it takes long time for African Americans to be treated equally, still the non-violence principles play an important 
role in gaining racial equality. The realization of non-violence principles through sit in, demonstration, and march can change the Whites' policy toward Blacks. Several policies that were used to discriminate and segregate African American's life almost in all aspects slowly change. Beginning with the desegregation in public facility, Whites slowly change their attitude toward African Americans.

\section{References}

Adjei, P. (2012). Mahatma Gandi and Martin Luther King Jr in the $21^{\text {st }}$ Century. Toronto: University of Toronto.

Bosmajian, H. (1967). Rhetoric of Martin Luther King's Letter from Birmingham Jail. Midwest Quarterly.

Bringing History Home. (2005). Mississippi Jim Crow Law. Retrieved from http://www.bringinghistoryhome.org/assets/ bringinghistoryhome/3rd-grade/unit2/activity-5/3_Mississippi_JimCrow.pdf

Bruns, R. (2006). Martin Luther King, Jr: A Biography. London: Greenword Press.

Blair, W and J. C. Greber. Factual Prose. Chicago. Scott, Foresman and Company.

Bond, J. (1999). Non-Violence: An Interpretation of Freedom Ways. Meet the Press.

Creswell, J. (2009). Qualitative Inquiry and Research Design. USA: Sage Publication Inc.

Davis, R. (2014). Creating Jim Crow: In Depth Essay. Retrieved from http://www.voyager.dvc.edu/ mpowell/afa $\mathrm{m} /$ creating2.pdf.

Du Bois, E. (1996). African American Political Thought, 1890-1930. Garland Publisher.

Franklin, J. H. (1991). Race and History: Selected Essays 1938-1988. Lsu Press.
Friedman, M. (2008). Free at Last. Bureau of International Program: http://www.america.gov

Irwin, B and Gordon, F. (1984). Why NonViolence? Introduction to Non-Violence Theory and Strategy. New Society Publishers.

Garrow, D. (1987). Martin Luther King Jr and the Spirit of Leadership. The Journal of American History, vol. 74, September.

Goldfield, D. R. (1987). Promised Land: the South Since 1945. Illinois: Harlan Davidson, Inc.

Guillen, C. (1993). The Challenge of Comparative Literature. President and Fellow of Harvard College.

Harris, T. (2010). African American Protest Poetry. Retrieved from http://nationalhumanitiescenter.org/tserve/fr eedom/1917beyond/essays/aaprotestpoetry. htm

Heath, J. F. (1976). Decade of Disillusionment: The Kennedy-Johnson Years. Bloomington: Indiana University Press.

Honey, M. (2003). Labor and Civil Right Movement at the Crossroads. Seattle: University of Washington.

Johnson, P. A. (1999). History of The American People. New York: Harper Collins Publisher.

Koliussi, L. (2004). Language and Literacy in The City's Neighborhoods. New Jersey: Lawrence Erlbaum Association Publishers.

King, M. L. (1954). Rediscovering Lost Values. February. Retrieved from https://swap.stanford.edu/20141218223358/ http://mlkkpp01.stanford.edu/primarydocuments/Vol 2/540228RediscoveringLostValues.pdf

King, M. L. (2015). Our God Is Marching On. March 1965. Retrieved from https://kinginstitute.stanford.edu/our-godmarching. 
King, M. L. (2015). Loving Your Enemies. June 1957. Retrieved from http://kingencyclopedia.stanford.edu/encycl opedia/documentsentry/doc_loving_your_e nemies/

King, M. L. (2015). Great March On Detroit. June 1963. Retrieved from http://kingencyclopedia.stanford.edu/encycl opedia/documentsentry/doc_speech_at_the _great_march_on_detroit.1.html.

King, M. L. The Letter From Birmingham Jail. August 1963. Retrieved from http://www.uscrossier.org/pullias/wpcontent/uploads/2012/06/king.pdf.

King, M. L. (2010). Strive Forward to Freedom. Beacon Press.

Ladenburg, T. (2007). Discrimination in Public Accommodation. Retrieved from http://www.digitalhistory.uh.edu/teachers/p dfs/unit11_4.pdf

Laurenson, D and Swingewood, A. (1972). The Sociology of Literature. London: Granada Publishing Limited.

LaFayette, B. (2004). The Role of Religion in Civil Right Movement. Retrieved from https://www.americanprogress.org/pdf.

Levy, P. B. (2003). The Civil Right Movement in Cambridge, Maryland. University Press of Florida.

Levy, M. (1965). The Black Experience in America: From Civil Rights to Present. New York: Britanicca Educational Publishing.

Lewis, J. (1965). March From Selma to Montgomery, "Bloody Sunday." Retrieved from http://www.archives/exhibits/eyewitness/ht $\mathrm{ml}$.

Lomax, L. When Non-Violence Meets Black Power. Los Angeles: Holloway House. 1968.

Lyman, R. 2011. Stanford in Turmoil. Stanford Historical Society. Retrieve from
http://historicalsociety.stanford.edu/pdfST/ ST35no1.pdf

Martin, J. K. et al. (1989). America and Its People. USA: Harper Collins Publishers. 1989

Mc Dowell, T. (1948). American Studies. Minneapolis: The University of Minnesota Press.

Morris, A. D. (1984). The Origins of the Civil Rights Movement: Black Communities Organizing For Change. New York: Free Press.

Norton, M. B. et al. (1986). American Society During the Postwar Boom 1945-1960s. Boston: Houghton Mifflin Company.

Nimer, A. (September 2004). Nonviolence in the Islamic Context. Retrieved from http://forusa.org/fellowship/2004/september -october/nonviolence-islamiccontext/12208

Patton, M. Q. (2002). Qualitative Research and Evaluation Methods (2nd edition). Newburry Park, CA: Sage.

Parks, Rosa. Rosa Parks: My Story. New York: Dial Books. 1991.

Parillo, V. (2008). Stranger To These Shores: Race and Ethnic Relations in The United States. Boston: Allyn and Bacon.

Pilgrim, D. (2000). What Was Jim Crow? Ferris State University. 2000. Retrieved from http://www.bringinghistoryhome.org/assets/ bringinghistoryhome/3rd-grade/unit2/activity-5/Crow.htm

Roses, L. E. and Randolph, R. E. (1997). Harlems Glory: Black Women Writing 1900-1950.

Sitkof, H. (1981). The Struggle for Black Equality. New York: Harper Collins Ltd.

Sunnemark, F. (2004). Ring Out Freedom. Indiana University Press.

Summy, R. Understanding Non-Violence in Theory and Practice. Peace, Literature, and Art, Vol. 2, 2002. The Martin Luther King 
Jr, Papers Project. Retrieved from http://kingencyclopedia.stanford.edu/primar ydocuments/Vol2Intro.pdf.

The American Postal Worker. (2005). Memphis 1968: Sanitation Workers Strike. Retrieved from http://www.apwuiowa.com/memphis \%20strike\%201968.pdf.

Trotter, J. W. (2001). The African American Experience. Boston: Hougton Miffin Company.
Smith, H. N. (2007). Virgin Land: The American West as Symbol and Myth. Cambridge: Harvard University Press.

Williams, D. (2005). The Thunder of Angels: The Montgomery Bus Boycott and the People who Broke the Back of Jim Crow. Chicago: Lawrence Hill Books.

Zattz, M. and Coramae, M. (2006). Images of Color, Images of Crime. Oxford University Press. 